\title{
Sektor Unggulan dan Transformasi Ekonomi di Kabupaten Badung
}

\author{
NI MADE LODI DWI UTAMI, MADE ANTARA, \\ I G. A. OKA SURYAWARDANI \\ Program Studi Agribisnis, Fakultas Pertanian, Universitas Udayana \\ Jalan PB. Sudirman Denpasar 80323 \\ Email: lodidwiutami26@gmail.com \\ antara_unud@yahoo.com
}

\section{Abstract \\ Leading Sector and Transformation of Economic in Badung Regency}

The development of tourism in Badung regency is rapidly causing inequality of regional development between north and south and the imbalance of development between economic sectors. The purpose of this study is to analyze the basic sectors and economic structure in Badung Regency. This study uses secondary data in the form of data of Gross Regional Domestic Product (GRDP), growth rate, and data of working population. Data collection methods used were documentation studies and analyzed using location quotient, dynamic location quotient, total shift share, and shift share. The results of analysis showed that the basis sectors in economic structure of Badung Regency is water supply, waste, and recycling sector, construction sector, transportation and warehousing sector, accommodation and feeding supply sector, and information and communications. The agricultural subsector has three sub-sub-sectors that are able to become the basis sub-subsector in the future are food crop sub-sub-sectors, horticultural crops sub-subsector, and fishery sub-sector. Two factors causing the change of agriculture, forestry and fishery subsector positions in the economic structure of Badung Regency, namely economic structure and location factor. The economic structure of Badung Regency is transformed from agriculture to services, especially tourism services, followed by shifts in labor absorption.

Keywords: leading sector, transformation of economic, Badung Regency

\section{Pendahuluan}

\subsection{Latar Belakang}

Pembangunan ekonomi biasanya dikaitkan dengan perkembangan ekonomi di negara berkembang (Sukirno, 2002). Pertumbuhan ekonomi secara regional dapat dilihat dari perubahan yang terjadi pada Produk Domestik Regional Bruto (PDRB). Kabupaten Badung merupakan salah satu kabupaten yang terdapat di Propinsi Bali yang mampu memberikan kontribusi besar terhadap pertumbuhan ekonomi Provinsi Bali yaitu menyumbang sebesar Rp 29.178,33 miliar atau 22,56 persen (BPS Propinsi Bali, 2016). Perkembangan pariwisata membuat wilayah Badung Selatan dengan perekonomian yang terus berkembang jika dibandingkan dengan wilayah 
Badung Utara dan Badung Tengah yang masih didominasi oleh pertanian, dimana sebagian besar masyarakat wilayah tersebut dengan mata pencaharian sebagai petani (BPS Kabupaten Badung, 2016). Hal tersebut yang menyebabkan terjadinya ketimpangan pembangunan yang berdampak terhadap distribusi pendapatan masyarakat (Rahardja dan Manurung, 2008). Sebagian besar perekonomian Kabupaten Badung didominasi oleh lapangan usaha jasa terutama lapangan usaha jasa pariwisata yang merupakan penunjang perekonomian Kabupaten Badung. Kondisi tersebut menunjukkan bahwa adanya kemungkinan terjadinya pergeseran struktur perekonomian Kabupaten Badung.

Berdasarkan uraian sebelumnya, terjadi ketimpangan pembangunan antar wilayah di Kabupaten Badung, sehingga diperlukannya penelitian mengenai identifikasi sektor dan subsektor unggulan pada sektor pertanian untuk mengetahui potensi wilayah Badung Utara dan Badung Tengah, serta penelitian mengenai transformasi ekonomi di Kabupaten Badung.

\subsection{Rumusan Masalah}

Berdasarkan latar belakang masalah yang telah dikemukakan maka permasalahan yang akan dikaji dalam penelitian ini sebagai berikut.

1. Apakah sektor dan subsektor unggulan pada sektor pertanian dalam perekonomian Kabupaten Badung?

2. Bagaimana transformasi ekonomi di Kabupaten Badung?

\subsection{Tujuan Penelitian}

Berkaitan dengan rumusan masalah di atas, maka tujuan dari penelitian sebagai berikut.

1. Mengidentifikasi sektor dan subsektor unggulan pada sektor pertanian dalam perekonomian Kabupaten Badung.

2. Menganalisis transformasi ekonomi (struktur ekonomi dan penyerapan tenaga kerja) dalam perekonomian Kabupaten Badung.

\section{Metode Penelitian}

\subsection{Lokasi dan Waktu Penelitian}

Penelitian ini dilakukan di Kabupaten Badung Propinsi Bali dengan waktu pelaksanaan pada bulan April sampai Mei 2017.

\subsection{Metode Pengumpulan Data}

Metode pengumpulan data dalam penelitian ini menggunakan studi dokumen adalah teknik pengumpulan data dengan meneliti berbagai dokumen yang akan digunakan sebagai bahan analisis (Sugiyono, 2013), dalam penelitian ini dokumen yang digunakan adalah PDRB, jumlah penduduk yang bekerja menurut lapangan usaha, dan laju pertumbuhan Propinsi Bali dan Kabupaten Badung. 


\subsection{Jenis dan Pengukuran Variabel}

Variabel yang digunakan dalam penelitian ini yaitu sektor dan subsektor unggulan pada sektor petanian dengan indikator PDRB dan laju pertumbuhan Kabupaten Badung dan Propinsi Bali, dianalisis menggunakan LQ, DLQ, dan TSS, sedangkan untuk variabel transformasi ekonomi di Kabupaten Badung dengan indikator PDRB dan jumlah tenaga kerja di Kabupaten Badung dan Popinsi Bali, dianalisis menggunakan shift share.

\subsection{Metode Analisis Data}

Metode analisis data yang digunakan untuk penentuan sektor dan subsektor unggulan pada sektor pertanian menggunakan analisis location quotient (LQ), dynamic location quotient (DLQ), dan total shift share (TSS) dan untuk mengetahui transformasi ekonomi Kabupaten Badung menggunakan analisis shift share.

\section{Hasil dan Pembahasan}

\subsection{Identifikasi Sektor Unggulan dan Subsektor Unggulan pada Sektor Pertanian}

\section{A. Hasil identifikasi sektor unggulan}

Untuk mengetahui sektor unggulan yang terdapat di suatu wilayah digunakan alat analisis yaitu Location Quotient (LQ) merupakan suatu perbandingan tentang besarnya peranan suatu sektor di suatu daerah terhadap besarnya peranan sektor tersebut secara nasional (Tarigan, 2005). Hasil identifikasi sektor unggulan dapat diketahui melalui Tabel 1 sebagai berikut.

Tabel 1.

Hasil Identifikasi Sektor Unggulan di Kabupaten Badung

\begin{tabular}{|c|c|c|c|}
\hline Kategori & Lapangan usaha & Rata-rata LQ & Ket. \\
\hline A & Pertanian, kehutanan, dan perikanan & 0,510 & Non basis \\
\hline $\mathrm{B}$ & Pertambangan dan penggalian & 0,305 & Non basis \\
\hline $\mathrm{C}$ & Industri pengolahan & 0,690 & Non basis \\
\hline $\mathrm{D}$ & Pengadaan listrik dan gas & 0,985 & Non basis \\
\hline $\mathrm{E}$ & Pengadaan air, pengolahan sampah, limbah dan daur ulang & 1,348 & Basis \\
\hline $\mathrm{F}$ & Konstruksi & 1,042 & Basis \\
\hline G & $\begin{array}{l}\text { Perdagangan besar dan eceran;reparasi mobil dan sepeda } \\
\text { motor }\end{array}$ & 0,856 & Non basis \\
\hline $\mathrm{H}$ & Transportasi dan pergudangan & 2,491 & Basis \\
\hline I & Penyediaan akomodasi dan makan minum & 1,327 & Basis \\
\hline $\mathrm{J}$ & Informasi dan komunikasi & 1,174 & Basis \\
\hline $\mathrm{K}$ & Jasa keuangan dan asuransi & 0,698 & Non basis \\
\hline $\mathrm{L}$ & Real estate & 0,839 & Non basis \\
\hline $\mathrm{M}, \mathrm{N}$ & Jasa perusahaan & 0,740 & Non basis \\
\hline $\mathrm{O}$ & Administrasi pemerintahan, pertahanan dan jaminan sosial & 0,677 & Non basis \\
\hline $\mathrm{P}$ & Jasa pendidikan & 0,687 & Non basis \\
\hline Q & Jasa kesehatan dan kegiatan sosial & 0,650 & Non basis \\
\hline $\mathrm{R}, \mathrm{S}, \mathrm{T}, \mathrm{U}$ & Jasa lainnya & 0,527 & Non basis \\
\hline
\end{tabular}

Sumber : diolah dari data sekunder 
Sektor unggulan yang berpotensi untuk dikembangkan di Kabupaten Badung dengan nilai LQ lebih besar satu meliputi sektor pengadaan air, pengolahan sampah, limbah, dan daur ulang, sektor konstruksi, sektor transportasi dan pergudangan, sektor peyediaan akomodasi dan makan minum, dan sektor informasi dan komunikasi, artinya peranan sektor tersebut di daerah lebih menonjol daripada peranan sektor yang sama di Propinsi Bali. Begitu pula sebaliknya dengan nilai LQ lebih kecil satu termasuk ke dalam sektor non basis yaitu terdiri 13 sektor.

\section{B. Hasil identifikasi statik subsektor unggulan pada sektor pertanian}

Analisis LQ pada subsektor pertanian untuk mengetahui subsektor unggulan dan mampu memberikan gambaran mengenai perencanaan pembangunan pada sektor pertanian (Hendayana, 2013). Hasil analisis diketahui sebagai berikut.

\section{Tabel 2.}

Hasil Identifikasi Subsektor Unggulan pada Sektor Pertanian di Kabupaten Badung

\begin{tabular}{lcl}
\hline \multicolumn{1}{c}{ Subsektor Unggulan } & Rata-rata & \multicolumn{1}{c}{ Ket. } \\
\hline 1. Pertanian, peternakan, perburuan dan jasa pertanian & 1,241 & Basis \\
a. Tanaman pangan & 1,273 & Basis \\
b. Tanaman hortikultura semusim & 1,060 & Basis \\
c. Perkebunan semusim & 0,099 & Non basis \\
d. Tanaman hortikultura tahunan dan lainnya & 1,102 & Basis \\
e. Perkebunan tahunan & 0,188 & Non basis \\
f. Peternakan & 1,618 & Basis \\
g. Jasa pertanian dan perburuan & 1,203 & Basis \\
2. Kehutanan dan penebangan kayu & 0,079 & Non basis \\
3. Perikanan & 0,392 & Non basis \\
\hline
\end{tabular}

Sumber : diolah dari data sekunder

Subsektor pertanian unggulan dengan LQ lebih besar satu meliputi subsektor pertanian, peternakan, perburuan, dan jasa pertanian, sub subsektor tanaman pangan, sub subsektor tanaman hortikultura semusim, sub subsektor tanaman horikultura tahunan dan lainnya, sub subsektor peternakan, dan sub subsektor jasa pertanian dan perburuan, artinya peranan subsektor tersebut di daerah lebih menonjol daripada peranan subsektor yang sama di Propinsi Bali, begitu pula sebaliknya dengan nilai LQ lebih kecil satu meliputi sub subsektor perkebunan semusim, sub subsektor perkebunan tahunan, subsektor kehutanan dan penebangan kayu, serta subsektor perikanan.

\section{Hasil identifikasi dinamik subsektor unggulan pada sektor pertanian}

Menurut Suyatno (2000), kelemahan metode LQ adalah bahwa kriteria ini bersifat statis yang hanya memberikan gambaran pada satu titik waktu. Kelemahan metode LQ dapat diatasi menggunakan dynamic location quotient (DLQ), yaitu 
dengan mengintroduksikan laju pertumbuhan. Hasil identifikasi DLQ dapat diketahui pada Tabel 3 sebagai berikut.

Tabel 3.

Hasil Identifikasi DLQ Subsektor Pertanian, Kehutanan, dan Perikanan Kabupaten Badung

\begin{tabular}{lcl}
\hline \multicolumn{1}{c}{ Subsektor Pertanian } & DLQ & \multicolumn{1}{c}{ Ket. } \\
\hline $\begin{array}{l}\text { 1. Pertanian, peternakan, perburuan dan jasa } \\
\text { pertanian }\end{array}$ & 0,94 & Non Basis \\
a. Tanaman pangan & 5,51 & Basis \\
b. Tanaman hortikultura semusim & 12,28 & Basis \\
c. Perkebunan semusim & 0,38 & Non Basis \\
d. Tanaman hortikultura tahunan dan lainnya & 0,49 & Non Basis \\
e. Perkebunan tahunan & 0,37 & Non Basis \\
f. Peternakan & 0,9 & Non Basis \\
g. Jasa pertanian dan perburuan & 0,28 & Non Basis \\
2. Kehutanan dan penebangan kayu & 0,58 & Non Basis \\
3. Perikanan & 1,76 & Basis \\
\hline
\end{tabular}

Sumber : diolah dari data sekunder

Subsektor pertanian memiliki tiga subsektor dengan DLQ lebih besar satu meliputi sub subsektor tanaman pangan, sub subsektor tanaman hortikultura semusim, dan subsektor perikanan, berarti laju pertumbuhan sub subsektor tersebut mengalami pertumbuhan yang lebih cepat dibandingkan laju pertumbuhan sub subsektor yang sama di Propinsi Bali. Hal tersebut disebabkan oleh peningkatan PDRB sub subsektor lebih cepat dibandingkan peningkatan PDRB sub subsektor yang sama di Propinsi Bali, begitu pula sebaliknya dengan nilai DLQ lebih kecil satu.

Perubahan posisi yang dialami subsektor pertanian di Kabupaten Badung menggunakan analisis gabungan metode LQ dan DLQ (Tabel 2 dan Tabel 3). Subsektor pertanian memiliki tiga subsektor yang mampu menjadi subsektor unggulan di masa mendatang meliputi sub subsektor tanaman pangan, sub subsektor tanaman hortikultura semusim, dan subsektor perikanan.

\section{Faktor penyebab perubahan subsektor unggulan pada sektor pertanian}

Menurut Suyatno (2000), metode LQ maupun DLQ hanya menunjukkan posisi dan reposisi sektoral dalam pertumbuhan ekonomi daerah tanpa membahas sebab perubahan tersebut. Oleh karena itu, untuk mengetahui penyebab perubahan digunakan analisis total shift share (TSS). Hasil identifikasi TSS dapat diketahui pada Tabel 4 sebagai berikut. 
Tabel 4.

Hasil Identifikasi Total Shift Share Subsektor Pertanian, Kehutanan, dan Perikanan

\begin{tabular}{lccc}
\multicolumn{4}{c}{ Kabupaten Badung } \\
\hline \multicolumn{1}{c}{ Subsektor Pertanian } & $\begin{array}{c}\text { SSS } \\
\text { (Rp juta) }\end{array}$ & $\begin{array}{c}\text { LSS } \\
\text { (Rp juta) }\end{array}$ & $\begin{array}{c}\text { Faktor } \\
\text { Penyebab }\end{array}$ \\
\hline $\begin{array}{l}\text { 1. Pertanian, Peternakan, } \\
\text { Perburuan dan Jasa } \\
\begin{array}{l}\text { Pertanian } \\
\text { a. Tanaman Hortikultura }\end{array}\end{array}$ & $84.914,29$ & $973.248,39$ & Faktor lokasi \\
$\quad$ Tahunan dan lainnya & $-794.140,17$ & $6.237,96$ & Faktor lokasi \\
$\begin{array}{l}\text { b. Peternakan } \\
\text { c. Jasa Pertanian dan }\end{array}$ & $-1.755 .925,97$ & $601.680,93$ & Faktor lokasi \\
$\quad$ Perburuan & $26.977,45$ & $-13.114,04$ & $\begin{array}{c}\text { Struktur } \\
\text { perekonomian } \\
\text { 2. Perikanan }\end{array}$ \\
\hline
\end{tabular}

Sumber : diolah dari data sekunder

Faktor penyebab perubahan peranan beberapa subsektor pertanian dari sektor basis menjadi sektor nonbasis meliputi subsektor pertanian, peternakan, perburuan, dan jasa pertanian, sub subsektor tanaman hortikultura tahunan dan lainnya, dan sub subsektor peternakan disebabkan oleh faktor lokasi, serta sub subsektor jasa pertanian dan perburuan disebabkan oleh struktur perekonomian. Perubahan peranan dari sektor nonbasis menjadi basis yang disebabkan oleh faktor lokasi adalah subsektor perikanan.

\subsection{Transformasi Ekonomi Kabupaten Badung}

\section{A. Transformasi struktur ekonomi}

Analisis shift share merupakan teknik yang sangat berguna dalam menganalisis perubahan struktur ekonomi daerah dibandingkan dengan perekonomian nasional. Faktor-faktor penyebab perubahan sektoral terdapat tiga komponen yaitu pertumbuhan nasional $(\mathrm{N})$, proportional shift $(\mathrm{M})$, differential shift $(\mathrm{C})$ (Arsyad, 1999). Hasil analisis shift share Kabupaten Badung pada Tabel 5 diperoleh nilai perubahan sebesar Rp 6.885.627 juta. Pertumbuhan tersebut dipengaruhi oleh tiga komponen yaitu regional share sebesar Rp 6.506.780,9 juta, bauran industri sebesar Rp 145.834,5 juta dan keunggulan kompetitif sebesar Rp 203.011,7 juta (Tabel 5). Ketiga komponen tersebut mempengaruhi pertumbuhan PDRB Kabupaten Badung yang terbesar diberikan oleh komponen regional share. Hal ini berarti bahwa pertumbuhan PDRB Kabupaten Badung sangat dipengaruhi oleh pertumbuhan PDRB yang terjadi di Propinsi Bali.

Secara keseluruhan nilai regional share bernilai positif untuk semua sektor, artinya pertumbuhan perekonomian Propinsi Bali berdampak positif terhadap perekonominan di Kabupaten Badung. Nilai proportional shift (Mij) bernilai positif menggambarkan bahwa pertumbuhan ekonomi Kabupaten Badung secara umum 
lebih cepat dari pertumbuhan ekonomi Propinsi Bali. Nilai differential shift (Cij) bernilai positif memiliki nilai laju pertumbuhan yang lebih cepat dibandingkan sektor yang sama di Propinsi Bali. Secara keseluruhan sektor yang berkontribusi besar terhadap pertambahan nilai PDRB Kabupaten Badung adalah sektor penyediaan akomodasi dan makan minum. Hasil analisis shift share sebagai berikut.

Tabel 5.

Transformasi Struktur Ekonomi Kabupaten Badung Tahun 2011-2015

\begin{tabular}{|c|c|c|c|c|c|}
\hline \multirow[b]{2}{*}{ No. } & \multirow[b]{2}{*}{ Lapangan Usaha } & \multicolumn{3}{|c|}{ Komponen } & \multirow{2}{*}{$\begin{array}{c}\text { Perubahan } \\
\text { Struktur } \\
\text { Ekonomi } \\
\text { Total } \\
\text { Perubahan, } \\
\text { Dij } \\
\text { (Rp juta) }\end{array}$} \\
\hline & & $\begin{array}{c}\text { Share } \\
\text { Regional, } \\
\text { Nij } \\
\text { (Rp juta) }\end{array}$ & $\begin{array}{c}\text { Proportio- } \\
\text { nal Shift, } \\
\text { Mij } \\
\text { (Rp juta) }\end{array}$ & $\begin{array}{l}\text { Differenti-al } \\
\text { Shift, Cij } \\
\text { (Rp juta) }\end{array}$ & \\
\hline 1. & $\begin{array}{l}\text { Pertanian, kehutanan, dan } \\
\text { perikanan }\end{array}$ & $535.287,3$ & $-252.171,5$ & $62.631,7$ & $345.747,5$ \\
\hline 2. & Pertambangan dan penggalian & $24.652,7$ & $-11.933,7$ & $4.781,6$ & $17.500,7$ \\
\hline 3. & Industri pengolahan & $298.633,2$ & 42.369 & $21.719,9$ & $362.722,1$ \\
\hline 4. & Pengadaan listrik dan gas & $13.469,2$ & $-2.482,2$ & 749,0 & 11.736 \\
\hline 5. & $\begin{array}{l}\text { Pengadaan air, pengolahan } \\
\text { sampah, limbah dan daur ulang }\end{array}$ & $21.048,2$ & $-7.100,8$ & $2.412,4$ & $16.359,8$ \\
\hline 6. & Konstruksi & $604.667,3$ & $125.225,4$ & $13.118,1$ & $743.010,8$ \\
\hline 7. & $\begin{array}{l}\text { Perdagangan besar dan } \\
\text { eceran;reparasi mobil dan sepeda } \\
\text { motor }\end{array}$ & $480.776,7$ & $72.669,3$ & $35.388,1$ & $588.834,1$ \\
\hline 8. & Transportasi dan pergudangan & $1.251 .247,6$ & $-158.822,1$ & $-291.924,9$ & $800.500,6$ \\
\hline 9. & $\begin{array}{l}\text { Penyediaan akomodasi dan } \\
\text { makan minum }\end{array}$ & $1.648 .984,3$ & $128.225,6$ & $205.895,4$ & $1.983 .105,4$ \\
\hline 10. & Informasi dan komunikasi & $491.439,9$ & $94.196,3$ & $5.288,5$ & $590.924,7$ \\
\hline 11. & Jasa keuangan dan asuransi & 175.386 & $76.543,5$ & $37.011,4$ & $288.940,9$ \\
\hline 12. & Real estate & $258.847,5$ & $10.540,5$ & $44.891,8$ & $314.279,8$ \\
\hline 13. & Jasa perusahaan & 52.864 & $-1.798,4$ & $3.673,6$ & $54.739,2$ \\
\hline 14. & $\begin{array}{l}\text { Administrasi pemerintahan, } \\
\text { pertahanan dan jaminan sosial }\end{array}$ & $288.248,3$ & $-79.606,5$ & $32.150,1$ & $240.791,9$ \\
\hline 15. & Jasa pendidikan & $223.319,4$ & $65.112,1$ & $7.878,4$ & $296.309,9$ \\
\hline 16. & Jasa kesehatan dan kegiatan sosial & $83.640,6$ & $48.847,2$ & $13.217,9$ & $145.705,7$ \\
\hline 17. & Jasa lainnya & $54.268,5$ & $-3.979,4$ & $4.128,7$ & $54.417,9$ \\
\hline & Jumlah & $6.506 .780,9$ & $145.834,5$ & $203.011,7$ & $6.855 .627,0$ \\
\hline
\end{tabular}

Sumber : diolah dari data sekunder

\section{B. Transformasi struktur tenaga kerja}

Analisis shift share menganalisis perubahan berbagai indikator kegiatan ekonomi, seperti produksi dan kesempatan kerja, analisis dibagi tiga komponen 
dalam shift share yaitu pertumbuhan nasional $(\mathrm{N})$, proportional shift $(\mathrm{M})$, dan differential shift (C) (Nurlatifah, 2009). Hasil analisis sebagai berikut.

Tabel 6.

Hasil Analisis Transformasi Struktur Tenaga Kerja di Kabupaten Badung Tahun 2011-2015

\begin{tabular}{|c|c|c|c|c|c|}
\hline \multirow[b]{2}{*}{ No. } & \multirow[b]{2}{*}{ Lapangan Usaha } & \multicolumn{3}{|c|}{ Komponen } & \multirow[b]{2}{*}{$\begin{array}{c}\text { Total } \\
\text { Perubahan, } \\
\text { Dij } \\
\text { (orang) }\end{array}$} \\
\hline & & $\begin{array}{c}\text { Regio- } \\
\text { nal } \\
\text { Share, } \\
\mathrm{Nij} \\
\text { (orang) }\end{array}$ & $\begin{array}{l}\text { Proportion- } \\
\text { al Shift, } \\
\text { Mij } \\
\text { (orang) }\end{array}$ & $\begin{array}{c}\text { Differe- } \\
\text { ntial } \\
\text { Shift, } \\
\text { Cij } \\
\text { (orang) }\end{array}$ & \\
\hline 1. & $\begin{array}{l}\text { Pertanian, perkebunan, } \\
\text { kehutanan, dan perikanan }\end{array}$ & 2.322 & -5.070 & -7.772 & -10.520 \\
\hline 2. & $\begin{array}{l}\text { Pertambangan dan } \\
\text { penggalian }\end{array}$ & 57 & -392 & -593 & -928 \\
\hline 3. & Industri pengolahan & 2.443 & -2.846 & -9.854 & -10.256 \\
\hline 4. & Listrik dan air & 43 & -75 & -92 & -125 \\
\hline 5. & Bangunan & 1.511 & 133 & 889 & 2.533 \\
\hline 6. & $\begin{array}{l}\text { Perdagangan, rumah } \\
\text { makan, dan hotel }\end{array}$ & 5.333 & 22.863 & 15.733 & 43.929 \\
\hline 7. & $\begin{array}{l}\text { Angkutan, pergudangan, } \\
\text { dan komunikasi }\end{array}$ & 637 & -1.534 & 9.974 & 9.076 \\
\hline 8. & $\begin{array}{l}\text { Keuangan, asuransi, usaha } \\
\text { persewaan, dan bangunan }\end{array}$ & 829 & 867 & 5.999 & 7.695 \\
\hline 9. & $\begin{array}{l}\text { Jasa kemasyarakatan, } \\
\text { sosial, dan perorangan }\end{array}$ & 3.465 & -7.183 & -4.767 & -8.485 \\
\hline & Jumlah & 16.639 & 6.763 & 9.518 & 32.919 \\
\hline
\end{tabular}

Sumber : diolah dari data sekunder

Analisis shift share tenaga kerja di Kabupaten Badung (Tabel 6) mengalami pertumbuhan sebesar 32.919 orang tenaga kerja. Pertumbuhan tersebut dipengaruhi oleh tiga komponen yaitu regional share (Nij) sebesar 16.639 orang, bauran industri (Mij) sebesar 6.763 orang, dan keunggulan kompetitif (Cij) sebesar 9.518 orang. Kontribusi terbesar disumbangkan oleh sektor perdagangan, rumah makan, dan hotel sebesar 43.929 orang, dan sektor dengan kontribusi terkecil disumbangkan oleh sektor pertanian sebesar -10.520 orang. Sama halnya dengan hasil analisis transformasi ekonomi (Tabel 5), pergeseran struktur perekonoian akan berdampak terhadap penyerapan tenaga kerja pada masing-masing sector. 


\section{Simpulan dan Saran}

\subsection{Simpulan}

Sektor unggulan di Kabupaten Badung meliputi sektor pengadaan air, pengolahan sampah, limbah, dan daur ulang, sektor konstruksi, sektor transportasi dan pergudangan, sektor peyediaan akomodasi dan makan minum, dan sektor informasi dan komunikasi. Subsektor pertanian yang merupakan subsektor unggulan meliputi subsektor pertanian, peternakan, perburuan, dan jasa pertanian, sub subsektor tanaman pangan, sub subsektor tanaman hortikultura semusim, sub subsektor tanaman horikultura tahunan dan lainnya, sub subsektor peternakan, dan sub subsektor jasa pertanian dan perburuan. Faktor penyebab perubahan peranan beberapa subsektor pertanian dari sektor basis menjadi sektor nonbasis yang disebabkan oleh faktor lokasi dan struktur perekonoman, sedangkan perubahan peranan dari sektor nonbasis menjadi basis yang disebabkan oleh faktor lokasi. Struktur ekonomi di Kabupaten Badung mengalami transformasi dari pertanian ke jasa khususnya jasa pariwisata yang diikuti oleh pergeseran penyerapan tenaga kerja.

\subsection{Saran}

Berdasarkan hasil analisis yang telah dilakukan dan simpulan yang diperoleh, maka saran yang dapat disampaikan yaitu dalam perencanaan pembangunan daerah, pemerintah Kabupaten Badung diharapkan memprioritaskan pembangunan sektor unggulan yang sudah teridentifikasi, sehingga mampu mengoptimalkan potensi sumber daya yang dimiliki. Sektor non basis khususnya sektor pertanian lebih diperhatikan dalam perencanaan pembangunan karena sektor pertanian di Kabupaten Badung, disamping sebagai sumber mata pencaharian untuk penduduk wilayah Badung Utara dan Tengah, juga sebagai sumber pasokan pangan wilayah Badung Selatan. Berdasarkan analisis shift share, Kabupaten Badung sangat tergantung pada Propinsi Bali atau delapan kabupaten/kota lainnnya, oleh karena itu pemerintah Kabupaten Badung sebaiknya tetap menjalin hubungan harmonisasi dengan kabupaten yang menunjang pariwisata Kabupaten Badung, dengan cara mengalokasikan pendapatan pariwisata berupa pajak hotel dan restoran ke kabupaten lainnya. Penelitian perlu dilanjutkan mengenai keterkaitan antar sektor ekonomi di Kabupaten Badung.

\section{Ucapan Terimakasih}

Ucapan terimakasih penulis sampaikan kepada semua pihak yang sudah membantu dalam menyelesaikan penelitian ini dan dapat dipublikasikan di e-jurnal.

\section{Daftar Pustaka}

Arsyad, Lincolin. 1999. Ekonomi Pembangunan Edisi Keempat. Bagian Peneritan YKPN. Yogyakarta.

Badan Pusat Statistik. 2016. Bali dalam Angka 2016. Denpasar : BPS Provinsi Bali. (http://bali.bps.go.id) 
Badan Pusat Statistik. 2016. Kabupaten Badung dalam Angka 2016. Badung : BPS Kabupaten Badung. (http://badungkab.bps.go.id)

Hendayana, Rachmat. 2003. Aplikasi Metode Locaton Quotient (LQ) Dalam Penentuan Komoditas Unggulan Nasional. Balai Pengkajian dan Pengembangan Teknologi Pertanian Bogor. Bogor.

Nurlatifah. 2009. Pergeseran Perekonomian Kabupaten Ciamis Pasca Pemekaran Kota Banjar. [Spripsi]. Fakultas Ekonomi dan Managemen, Institut Pertanian Bogor. Bogor.

Raharja dan Manurung. 2008. Pengantar Ilmu Ekonomi (Makroekonomi \& Mikroekonomi) Edisi Ketiga. Lembaga Penerbit Fakultas Ekonomi Universitas Indonesia. Jakarta.

Sugiyono. 2013. Metode Penelitian Bisnis (Pendekatan Kuantitatif, Kualitatif, dan $R \& D)$. Alfabeta. Bandung.

Sukirno, Sadono. 2002. Pengantar Teori Makroekonomi. PT Raja Grafindo Persada. Jakarta.

Suyatno. 2000. Analisa Economic Base Terhadap Pertumbuhan Ekonomi Daerah Tingkat II Wonogiri: Menghadapi Implementasi UU No. 22/1999 dan UU No. 5/1999. Jurnal Ekonomi Pembangunan Vol. 2, Desember:144-159. Fakultas Ekonomi Universitas Muhammadiyah Surakarta. Surakarta.

Tarigan, Robinson. 2005. Ekonomi Regional Teori dan Aplikasi. Bumi Aksara. Jakarta. 